\title{
MALNUTRITION IN THE SURGICAL PATIENTS
}

\author{
Andonovska J. Biljana, ${ }^{1}$ Kuzmanovska K. Biljana, ${ }^{1}$ Andonovski G. Alan, ${ }^{1}$ \\ Kartalov B. Andrijan, ${ }^{1}$ Petrovska Cvetkovska K. Dragana ${ }^{2}$ \\ ${ }^{1}$ University Clinic of Traumatology, Orthopedic Surgery, Anesthesiology, \\ Intensive Care Unit and Emergency Center, Skopje, R. Macedonia \\ ${ }^{2}$ University Clinic for Neurology, Faculty of Medicine, \\ University "Ss. Cyril and Methodius" Skopje, Republic of Macedonia
}

Primljen/Received 09. 05. 2016. god.

Abstract: The term "malnutrition" is a broad term used to describe any imbalance in the diet. In 2009 it was confirmed that malnutrition is an urgent health problem. The reasons for which malnutrition may develop are different. Loss on cellular, physical and physiological level happens as a consequence of malnutrition. Studies show that in surgical practice there is malnutrition in $50 \%$ of patients and that there is an association between inadequate nutritional status and surgical result. It leads to prolonged treatment, increasing of the level of morbidity and mortality, increased hospital costs, etc. Sometimes malnutrition is unrecognised, untreated and worsened in hospitals. For this reason this paper will elaborate: nutrition and a surgical patient, assessment of a nutritional status, assessment of energy requirements, and enteral and parenteral nutrition in order to determine the conditions and procedures that affect the appearance, recognition and treatment of malnutrition.

Key words: malnutrition, surgical patient, nutritional assessment, assessment of energy requirements, enteral nutrition, parenteral nutrition.

\section{IINTRODUCTION}

The term "malnutrition" is a broad term used to describe any imbalance in the diet, ranging from over nutrition to under nutrition. According to the Declaration of ENHA of June 2009, it was confirmed that malnutrition is an urgent health problem throughout Europe. The reasons for which malnutrition may develop are different: scarce food intake, increased requirements related to the stage of a disease, complications of the primary disease expressed in reduced absorption or excessive loss of nutrients, or a combina-
Prihvaćen/Accepted 10. 08. 2016. god.

tion of all $(1,2)$. Loss on cellular, physical and physiological level occurs as a consequence of malnutrition (2). This loss is determined by the age of the patient, type, severity and duration of illness, and the current nutritional intake.

Studies show that in surgical practice there is malnutrition in $50 \%$ of patients and that there is a connection between the nutrition and surgical result. It leads to prolonged treatment, increasing of the level of morbidity and mortality, increased hospital costs, etc. (3). Professor Claude Pichard's opinion, in this context, says that: "Malnutrition has a high prevalence and it leads to poor clinical outcomes. Solution exists and an effective nutritional support improves the clinical expectations, and it is economically worthwhile. Now it is the time for action." Concerning the seriousness of the problem a conclusion has been made in order to undertake a series of complementary activities under the motto: STOP for the diseases related to malnutrition and for the diseases leading to malnutrition (4)!

Considering the previously mentioned, this paper will elaborate the following issues in order to determine the conditions and procedures that affect the appearance, recognition and treatment of malnutrition:

- Nutrition and a surgical patient,

- Assessment of a nutritional status,

- Assessment of energy requirements,

- Enteral and parenteral nutrition.

The paper will systematize everything that has been published and obtained by searching the data bases such as: Medline (OVID, 1948 - till now), Cochrane Central Register of Controlled Trials, Pub Med, and everything connected to the problem of malnutrition in a surgical patient. 


\section{MALNUTRITION AND THE SURGICAL PATIENTS}

Surgical patients are a heterogeneous population, with differences in primary diseases. Although differences exist separate in all patients, there is a similarresponse to stressfrom the surgical intervention which is represented with a complex of serial reactions involving the endocrine and inflammatory system. These reactions play an important role in the development of metabolic changes and in the development of postoperative complications.

With the start of the surgery, the patients get increased counter-regulatory hormones like cortisol, glucagon and catecholamines leading, among others, to increased energy consumption and start of protein catabolism. With the progress of molecular biology it has become clear that pro-inflammatory cytokines such as necrosis tumour factor - alpha TNF- $\alpha$ and interleukins IL-1, IL-6, IL-8 are important mediators of early protein catabolism concerning an injury and sepsis. The impaired balance between them and anti-inflammatory cytokines also plays a role in the occurrence of malnutrition or anorexia, pyrexia, and fat catabolism (5).The greater the stress is, the more catabolism gives reactions and influence, and as a consequence reduction in the normal insulin anabolic effect and development of insulin resistance may occur. An intensive catabolic response is difficult for the human organism, it is associated with a destruction of muscle tissue and reduction of energy supplies and it prolongs the recovery (6). Therefore, it is necessary to undertake measures to reduce the stress as a result of surgery and to support the anabolism during the surgical treatment (7).

In the pre-operative phase, the traditional and strict rule "nothing by mouth from midnight to the day of surgery" is applied in order to ensure an empty stomach. The preoperative diet is intended to reduce the risk of regurgitation, nausea and vomiting in patients with anaesthesia, and thus to prevent aspiration of stomach contents (8). Starvation is also important from surgical aspect, especially in stomach and intestines operations or in laparoscopic interventions where there is an increased intra-abdominal pressure and an increased chance of regurgitation.

The optimal time of starvation is questionable. There is consensus that clear solutions can be taken two to three hours before the intervention, and concerning the question of intake of solid food and milk, experiences vary between four and eight hours. According to recent studies, four to six hours for solid food and milk are recommended, and four hours for breastfeeding milk. According to Green C. R et al. excessive starvation will not provide optimal gastric environ- ment, but it can lead to dehydration, electrolyte imbalance, nausea, malnutrition, hypothermia, and irritability (9).

Recommendations are given by ESPEN for intake of carbohydrates instead of starving overnight. This recommendation is supported by the fact that the excessive starvation causes a rise in the inflammatory markers in the acute stress response phase, while the use of oral carbohydrate supplements two hours before the surgical intervention can have an effect on this reaction. The effects of this recommendation have been confirmed in the study by Zelic. According to this study the patients undergoing surgery on intestines due to a malignant disease should receive a carbohydrate drink in the evening and two hours before the surgery because reduction of postoperative thirst, hunger, dehydration, headache, nausea and vomitus have been noticed in all adult groups (10). In gastrointestinal operations the extended and reduced food intake is the cause of malnutrition, which of course is emphasized by the tumour cachexia and the reduced absorption as a result of intestinal obstruction or previous resection (5).

In the postoperative phase, the normal oral nutrition or nutrition through a tube should start within the first 24 hours. There are strong evidences that oral nutritional supplements ( $200 \mathrm{ml}$ twice daily) given on the day of the surgical intervention up to the normal food intake give positive benefit (11). The early postoperative nutrition decreases the response to stress and consequently decreases the insulin resistance and reduces the nitrogen loss and muscle mass loss (12).

The assessment of gastrointestinal function and tolerance of the patient is extremely important for the application of postoperative nutrition. In patients operated electively by resection of gastrointestinal tract, who take substances through the mouth reduction of infections and hospital stays has been determined opposite to the same group of patients who were not administered substances through the mouth (13). The positive effects of the early nutrition on reducing the incidence of anastomotic dehiscence, infection of a wound, pneumonia and intra-abdominal abscess is confirmed by Lewis et al. They pointed out the conclusion that there is no benefit to keep patients without oral nutrition after surgery (14).

Nutrition may be postponed in the postoperative period due to postoperative complications that have a negative effect on postoperative nutrition. Problems with intestines or postoperative ileus are the most common complication in surgical patients. It compromises postoperative nutrition, which leads to increased postoperative catabolism, worse wound healing, and greater possibility for infection $(14,15)$. Haemodynamic instability is another reason for the delayed start of en- 
teral nutrition. Trophic nutrition is recommended in those conditions (16).

\section{ASSESSMENT OF A NUTRITIONAL STATUS}

The assessment of a nutritional status is of particular importance because it affects the postoperative clinical results. The early recognition of malnutrition enables planning of nutrition therapy, prevention of inadequate nutritional status, as well as its cessation or correction so that the postoperative complications can be avoided (17).

For the diagnosis of malnutrition, the American Society of Parenteral and Enteral Nutrition (ASPEN) have recommended methods for assessing the nutritional status of hospital patients. These methods include criteria and data for nutritional needs, food intake, clinical picture of the patient, and anthropometric and laboratory parameters (18). Some of the parameters are: common and current weight, percentage of current loss of weight, height, body mass index (BMI), the upper arm circumference, the upper arm muscle mass, skinfold thickness at the level of triceps, total lymphocyte count, and serum albumins (19). There is no unique standard for identification of malnutrition. ASPEN (2002) proposes the Subjective Global Assessment (Subjective Global Assessment - SGA) for detection of malnutrition prevalence, and the European Society ESPEN proposes nutritional risk screening - 2002 (NRS-2002).

The simplest and oldest way to measure nutritional status is the body weight, compared to the previous or the ideal weight. The use of weight value as a single one for the assessment of nutrition as a method is considered to have characteristics with limiting estimate. In any case, the weight loss greater than $10 \%$ is a poor prognostic indicator (20).

The body mass index (BMI) is a more optimal nutritional indicator. Namely, in each scenario when BMI is less than $15 \mathrm{~kg} / \mathrm{m}^{2}$ the increase in morbidity is significant (21). The hospital patients with a BMI less than $18.5 \mathrm{~kg} / \mathrm{m}^{2}$ have longer stay in the unit for intensive care, increased frequency of postoperative complications, delayed start of oral nutrition etc (22). However, BMI, as a measure of evaluation, has low sensitivity in overweight patients. The increased BMI is associated with a heart disease, diabetes, hypertension, and an increased morbidity during surgery. Hence, a question arises whether the increased morbidity in the perioperative period is actually a result of malnutrition or of comorbidities in these patients. Accompanying diseases in these patients led to a change in water balance, oedema, and ascites that affects the estimations. All in all, BMI is a useful tool for assessment of nutrition in surgical patients who have a need and benefit from nutritional intervention.

Anthropometric methods are used in the general assessment of the nutritional status, but for acutely injured patients they showed as nonspecific.

Another method is the method of functional capacity and muscle power. With this method, which was first introduced by Klidijian in the 1980s, the reduction of muscle power is a better predictor of malnutrition and the complications in the postoperative period than the methods of weight loss and some anthropometric measures. The method of functional capacity and muscle power is useful, but its use is limited to the need for patient cooperation, which as a parameter is variable and subject to change under the influence of drugs (23).

Furthermore, in a prospective study of 100 patients undergoing major surgery of the gastrointestinal tract, Sungurtekin et al. concluded that $44 \%$ of the patients have malnutrition according to SGA, a $61 \%$ have malnutrition according to NRS (24).

SGA is a marker that integrates data received from the disease history, the clinical examination and image. Five characteristics received from the history of the disease and four characteristics received from the clinical examination enable assessment of nutritional status. The score obtained by applying this method ranks the patients as:

1. Well nourished (Grade A),

2. Moderately malnourished or at risk of malnutrition (Grade B), and

\section{Severely malnourished (Grade C).}

SGA and albumin are values that are useful to differentiate high risk from low risk patients. Detsky assesses these values as useful techniques for nutritional assessment of patients who need to undergo a major gastrointestinal surgery as a way to predict postoperative complications in nutrition (25).

NRS - 2002 is the method that assesses the weight loss, BMI, food intake, and severity of the disease. Based on this screening the patients can be classified with:

- No risk of malnutrition with value 0 ,

- Mild risk of malnutrition with a value of 1-2,

- Moderate risk of malnutrition with a value of 3-5,

- Severe risk of malnutrition with a value $>5$ (26).

The other marker or the so called nutritional risk index (NRI) is determined by serum albumin and the change in weight. Both markers, NRS and NRI, correlate with the extent and severity of postoperative complications in gastrointestinal surgery patients. Some studies show that patients, who suffer from serious illness and have serious nutritional risk as SGA- level B 
and NRS 2002 more than 3 points, would benefit from a perioperative nutritional support in the postoperative recovery and in their clinical results (27).

Reduced synthesis of negative proteins in the acute phase will result in decreased levels of serum albumin, transferrin, prealbumin and retinol which are a potent indicator of a poor result. Hence, it is advisable that albumin and prealbumin should not be used as isolated markers to assess the nutritional status because they are essential markers for the inflammatory metabolism and reflect the water balance. Positive acute phase proteins, such as CRP are also a potent predictor of morbidity and mortality and are increased and present in the period of inflammation (28).

In the evaluation of malnutrition, ESPEN protocols specify the nutritional risk screening 2002 (NRS-2002) and albumin below $30 \mathrm{~g} / 1$. In Jie's study it is found that patients who have a score of 5 or more, according to NRS scale for malnutrition benefit more from the perioperative nutritional support (29).

As it can be seen, there are many markers, methods or combination of methods having certain characteristics that may occur as advantages or disadvantages in certain situations. Nutritional status is determined by them which on the other hand is a marker itself for determination of the status of the disease.

\section{ASSESSMENT OF ENERGY REQUIREMENTS}

About patients who receive nutritional support there is always a question: are being fed appropriately? Studies in surgical patients have been reviewed to determine the 'optimal' energy and protein requirements of these patients. Uncomplicated surgery has energy requirements of 1.0-1.15 x BMR while complicated surgery requires $1.25-1.4 \times$ BMR in order to meet the patient's needs (30). Identifying the optimal requirements of ICU patients is more difficult because of the heterogeneous nature of this population. In general, 25 $\mathrm{kcal} / \mathrm{kg} / \mathrm{separate}$ considered as an appropriate target for surgical patients, but patients with sepsis or trauma may require almost twice as much energy (31). The measurement of energy expenditure is the most accurate method to assess energy needs. It can be done directly by putting a person in a calorimeter and measuring the amount of heat produced by the body mass but this is not very practical. Predictive equations are routinely used to determine energy needs in patients. There are nearly 200 published energy expenditure formulas dealing with various conditions, disease states, age, presence of obesity and other additional factors (32). One of the most frequently used formulas for predicted energy expenditure is the Harris-Benedict equations and they take into account gender, age, height and weight. Harris-Benedict Equations (calories/day):

Male: $(66.5+13.8 X$ weight $)+(5.0 X$ height $)-$ (6.8 Xage)

Female: $(665.1+9.6 X$ weight $)+(1.8 X$ height $)-$ (4.7 Xage)

weight in kilograms, height in centimetres, age in years (33).

Unfortunately there is no consensus about which predictive equation is the most accurate in surgical patientand the substantial error, when compared to indirect calorimetry is in the range of $7-55 \%$, leading to over- and underestimation of energy needs. The reasons are because many of the equations are based on static variables, and the surgical patients are known to show wide day-to-day fluctuations in metabolic rates. Another limitation of predictive equations is the failure to account for potential nutrient losses through diarrhea, wounds, fistulas, and haemodialysis. Another difficulty with energy determinations arises in the obese surgical patients and there is a question of which weight to use in predictive equations. Body composition consists of fat mass and fat-free mass which is the metabolically active component. The concern is that use of the actual body weight (ABW) in the obese patientswill overestimate energy needs, as much of the excess weight is metabolically inactive fat mass and that leads to overfeeding. That is why some practitioners prefer to use adjusted body weight (AjBW) or ideal body weight (IBW) in their calculations, but unfortunately there is still no consensus about this (34).

The gold standard for determining energy expenditure and requirements in the clinical setting is indirect calorimetry. This method calculates rest energy expenditure (REE), the amount of energy in calories required for basic metabolic processes of the body during a non-active period of 24-hours. It is measured indirectly with a indirect calorimetry equipment (metabolic cart) by analysis of respiratory gases (usually expired) to derive volume of air passing through the lungs, the amount of oxygen extracted from it and the amount of carbon dioxide, as a by-product of metabolism, expelled to atmosphere all computed to represent values corresponding to 1 minute time intervals.

With these measurements except REE, the respiratory quotient (RQ) can be also calculated. The abbreviated Weir equation is used to calculate the 24-hour energy expenditure.

\section{Abbreviated Weir Equation: \\ $\mathrm{REE}=[3.9(\mathrm{VO} 2)+1.1(\mathrm{VCO} 2)] 1.44$ \\ $\mathrm{VO} 2=$ oxygen uptake $(\mathrm{ml} / \mathrm{min})$ \\ $\mathrm{VCO} 2=$ carbon dioxide output $(\mathrm{ml} / \mathrm{min})$.}

Respiratory quotient $(\mathrm{RQ})=\mathrm{VCO} 2 / \mathrm{VO} 2(35)$. 
The amount of lean body mass is the primary determinant of REE, but multiple other factors can influence REE such as age, sex, presence of fever or inflammation, thyroid function etc. Sedation, analgesics, and neuromuscular blocking agents reduce REE, while pressors raise REE. The respiratory quotient (physiologic range $0.67-1.2$ ) reflects substrate oxidation and has different values such as 1.0 for glucose, 0.81 for proteins and 0.69 for lipids. It is theoretically useful in assessing a nutrition regimen, as overfeeding or excessive carbohydrate administration increases $\mathrm{VCO} 2$ and leads to an RQ $>1.0$, while underfeeding with associated lipolysis decreases the RQ. According to some specialists despite the theoretical usefulness of the RQ in nutrition titration, it has a low sensitivity and specificity as an indicator of over- and underfeeding. A number of confounding factors can increase or decrease the RQ, including acid-base disorders, hypo- or hyperventilation, and body habitus (36).

It is clear that the most important measurement for REE is VO2 but it needs indirect calorimetry equipment ("metabolic cart") which is expensive. That is why some specialists tried to find some equation to calculate the REE measuring only $\mathrm{VCO} 2$ with ventilator devices. The modified Weir equation (REE, $\mathrm{kcal} /$ day $=5.5 \times \mathrm{VCO} 2 \mathrm{~L} / \mathrm{min}) \times 1440 \mathrm{using}$ a fixed RQ of 0.89 ) waslater improved by Sandra Stapel and colleagues who proposed an even more sophisticated approach to achieve better accuracy using VCO2 alone in ventilated surgical patients, extracting RQ from the nutrition regimen for each evaluation and not using a fixed value (37).

However, while the use of complicated mathematics resulted in good precision and low bias, the concept does not reflect the complexity of physiology in the surgical patient. First the administered nutrients are only partially absorbed in these patients. Thus, small intestine glucose absorption is markedly impaired, independently of duodeno-cecal transit time while lipid absorption is reduced by almost half when compared with healthy volunteers. Secondly, endogenous glucose production is not depressed despite nutrition administration, adding a load of endogenous carbohydrates to the nutrient administration and autophagy provides endogenous lipids, carbohydrates and protein. Third, secondary to stress, there is significant insulin resistance as well as obligatory lipolysis and severe proteolysis which nutrients are unable to inhibit. Finally, body substrate oxidation obtained by indirect calorimetry is far from the nutrient administration, making the correlation between the prescription and the respiratory quotient more difficult. In addition, indirect calorimetry equipment ("metabolic cart") is expensive, requires technical expertise to operate, and is often unavailable in many institutions. It is inaccurate with $\mathrm{F}_{\mathrm{IO} 2} \geq 60 \%$, $\mathrm{PEEP} \geq 12 \mathrm{~cm} \mathrm{H}_{2} \mathrm{O}$, air leakage in the respiratory circuit (leaking chest tube or endotracheal cuff, bronchopleural fistula), haemodialysis, extreme pain or agitation, and with calibration errors. Inaccuracies inherent in these types of calculations or measurements may explain why some interventional nutrition studies fail to achieve positive clinical outcomes (38).

\section{PARENTERAL NUTRITION}

The first attempts of parenteral and experimental nutrition implemented on animals date back to the seventeenth century, but the actual development was recorded in twentieth century, which is identified as the era of development of parenteral nutrition. Namely, the research and practices of a group of doctors from Chicago presented in the study "Prolonged and carefully timed intravenous sugar" in 1915 emphasized the importance of carbohydrates, which opened the door for further research concerning amino acids, polypeptides, lipids and their use.

According to ESPEN the parenteral nutrition is favourable for malnourished patients for whom the enteral nutrition is not possible or is not tolerated and for patients with postoperative complications and loss of gastrointestinal tract function, where it is impossible for patients to receive and absorb sufficient quantities of food, either orally or enterally, more than 7 days. Routine use of parenteral nutrition has not proved beneficial for patients with good nutritional status and patients with adequate oral intake in the first week after surgery $(39,40)$.

Several studies show that parenteral nutrition 7-10 days before surgery improves postoperative results in patients with severe malnutrition. As a consequence of a direct venous administration, the parenteral nutrition can rapidly improve the nitrogen balance. It enables fast lymphocyte recovery and healing of wounds as well as reduction of infectious and non-infectious complications from $42.9 \%$ to $5.3 \%$ (41).

In the majority of patients the oral use of carbohydrates before surgery is recommended, which may be used by the intravenous route if oral intake of fluids and food is not allowed. Infusion of glucose of $5 \mathrm{mg} / \mathrm{kg}$ per minute and $20 \%$ solution can affect insulin resistance, protein metabolism, post-operative nausea and vomiting (42).

The question of whether the diet should be standard or customized remains open. It is known that cardiac patients could benefit from concentrated solutions of small volume, the patients with chronic renal failure require a reduced concentration of sodium, potassium and total volume, and the patients with gastrointestinal disorders, with metabolic and electrolyte imbalances require addition of electrolytes, vitamins and trace elements (43). 
Certainly, it should not be overlooked that the use of parenteral nutrition carries risks with itself, such as: volume overload with respiratory compromising, excessive carbohydrate infusion with elevated triglycerides, hepatic steatosis and hyper-glycaemia with immune disorder, feeding with azotaemia, hypertonic dehydration, metabolic acidosis, as well as hyper-capnia and refeeding syndrome as a result of the aggressive nutrition.

Science has been ambivalent towards parenteral nutrition and its use in surgical patients. If by 1988 the importance of parenteral nutrition and its impact on mortality was emphasized, after 1989 the results of the research have given a different answer. According to recent studies the parenteral nutrition does not show a significant benefit for surgical patients.

\section{ENTERAL NUTRITION}

Enteral nutrition means intake of food or commercial products through a tube or a stoma in the stomach, duodenum or jejunum. Preserved integrity of the small intestine mucous membrane and colon is necessary for its use. According to recent research on the gastrointestinal tract, intestinal mucosa and its integrity may be endangered by lack of food and it may in fact lead to atrophy of the intestinal mucosa and suppression of local immune response, to bacterial translocation and even to sepsis and multiorgan weakness. The basic rule in clinical nutrition says: "If the gastrointestinal tract works, use it".

Lesions of the central nervous system, anorexia, cancer, hyper metabolic conditions, burns, severe infections, and even intestinal inflammatory conditions are examples where enteral nutrition is indicated (44).

Immunonutrition is a new approach in diet. It is nutrition with added nutrients (immunoregulators) such as arginine, glutamine, omega 3 fatty acids, nucleotides, and antioxidant vitamins and minerals. Immunoregulators act favourably on the secretion of trophic hormones, on the synthesis of anti-inflammatory cytokines, on the reduction of immunosuppressive pro-inflammatory cytokines, on the improving of mesenterial circulation, on the wound healing, on protein synthesis, and also affect the reduction of proteolysis thus preventing bacterial translocation and subsequent infectious complications concerning extended hospital stays.

M. Braga's et al., study is in favor of this context. It was conveyed on 206 patients with gastrointestinal malignancy, where the group administered immunonutrititon through jejunal tube showed significant reduction of infectious complications ( $14 \%$ vs. $30 \%$ ) and also in the length of hospital stays (11.1 vs. 12.9 days) (45). In his study, Senkal M et al., included 164 patients with cancer on the upper gastrointestinal tract and analysed and compared the complications between pa- tients receiving postoperative immunonutrition through jejunostoma and those treated with standard nutrition. It was noted that the early postoperative complications were similar in both groups, while the complications after the 5th day were significantly reduced in patients with immunonutrition (46).

The quantity and time of enteral nutrition are also important factors. In some cases a minor amount in the intestinal lumen $(<200 \mathrm{ml} / 24 \mathrm{~h})$ may prevent atrophy of the intestinal villi and affect reduction of bacterial translocation as well as of other complications. These are cases of so called minimal enteral nutrition (47).

Regarding the time of giving, according to a study by Payne J. et al., where patients with abdominal operations (gastrectomy, colon resections) were involved, the group of patients who received enteral nutrition 4 hours after surgery showed significantly lower number of postoperative infections compared to the group with placebo (48).

However, despite the advantages, complications in enteral nutrition may occur. They are divided into mechanical, metabolic and gastric-intestinal. Mechanical complications are: setting a tube into respiratory paths, its displacement, blockage and relegation. Metabolic complications occur in $30-40 \%$ of patients and are in a form of disturbance of water electrolyte balance, such as: hypophosphatemia or hyperphosphatemia, magneziemia, glucose, and metabolic acidosis. Gastric intestinal complications include distensia, sickness, nausea, vomiting, and diarrhea. It is considered that diarrhea occurs in $10-15 \%$ of the patients.

\section{ENTERAL VERSUS PARENTERAL NUTRITION}

Good nutrition must include adequate intake of energy, nitrogen, vitamins and trace elements (49). Enteral nutrition is considered to be the most adequate and superior way of nutrition. More facts support this stance. Namely, the enteral nutrition is considered to have a wide spectrum of applications by which it provides nutrition in different clinical conditions. It is more cost effective, more secure, with simpler and safer maintenance of nutrition, metabolic and immune function, with maintenance of gastrointestinal barrier and preserving the integrity of enterocytes and colonocytes as well as with preventing bacterial translocation (50).

Complications such as intra-abdominal abscess and pneumonias are more common in patients having parenteral nutrition compared to patients with enteral nutrition. The number of lymphocytes in the intestinal mucosa and the respiratory and intestinal IgA levels were reduced in patients receiving parenteral nutrition. Enteral nutrition is a well-known factor in the healing of intestinal anastomoses (51). However, some patients 
prefer parenteral nutrition instead of enteral nutrition through tubes, and others despite having a functioning gastrointestinal tract, are unable to tolerate oral or enteral nutrition as a result of anorexia, dysphagia, etc. For these and other reasons parenteral nutrition is an affordable choice of nutrition in some cases.

\section{THE COMBINATION OF ENTERAL} AND PARENTERAL NUTRITION

Enteral nutrition cannot always meet the energy needs of patients. According to ESPEN, the combination of enteral and parenteral nutrition should be considered for patients who need nutritional support, and where more than $60 \%$ of the requirements cannot be met by the enteral route. The benefit of enteral parenteral combination is unclear.

According to Heidegger et al. the use of parenteral nutrition as a supplement, after the 4-th days of admission is considered to cause a reduction of nosocomial infections and improving of clinical results in patients where the enteral nutrition does not achieve the energy target (52). In a small retrospective study it was showed that the combination of enteral-parenteral nutrition in patients with acute pancreatitis affects not only the evolution of the disease but also the complications and the overall result of the treatment.

In a multicentre study involving more than 4,000 critically ill patients, Casaer MP., reported that an early use of parenteral nutrition as an addition to enteral nutrition, causes an increase in infections and an increased incidence of cholestasis (53). In another retrospective study done by Hsu in a surgical intensive care unit, it was shown that the patients fed enterally by an increased amount of $10 \%$ of the total estimated calories, better clinical results were achieved (54). According to the results of these studies and the results of other researchers, it can be concluded that enteral nutrition should be always administered when it is possible.

\section{CONCLUSION}

Malnutrition is a well-known major risk factor for poor postoperative results. Understanding of the physi- ological developments in a surgical patient, as well as the advancement of diagnostic tools enable a clinician to identify preoperative malnutrition or risk of malnutrition and thus to determine who needs nutritional therapy in order to prevent postoperative complications related to malnutrition. Enteral nutrition is a superior choice. In cases where more than $60 \%$ of energy needs cannot be met by enteral intake, combination with parenteral nutrition should be considered. Routine use of parenteral nutrition has not proved useful, but the use of parenteral nutrition 7-10 days before surgery improves postoperative results in patients with severe malnutrition. Inadequate oral intake in a period longer than 14 days leads to higher mortality.

\section{Conflict of interest}

The authors declare that there is no conflict of interest.
Abbreviations
ENHA - European Nutrition Health Alliance
TNF- $\alpha$ - Necrosis tumor factor - alpha
IL - Interleukins
ESPEN - The European Society for Clinical Nutrition and Metabolism

ASPEN - American Society of Parenteral and Enteral Nutrition

BMI - Body mass index

SGA - Subjective Global Assessment

NRS - 2000 - Nutritional risk screening - 2002

NRI - Nutritional risk index

CRP - C - Reactive protein

BMR - Basal metabolic rate

ABW - Actual body weight

AjBW - Adjusted body weight

IBW - Ideal body weight

REE - Rest energy expenditure

$\mathbf{R Q}$ - Respiratory quotient

V02 - Oxygen uptake

VCO2 - Carbon dioxide output

FiO2 - Fraction of inspired oxygen

PEEP - Positive end - expiratory pressure

Ig A - Immunoglobuline A

\title{
Sažetak
}

\section{MALNUTRICIJA KOD HIRURŠKIH BOLESNIKA}

\author{
Andonovska Biljana, Kuzmanovska Biljana, Andonovski Alan, \\ Kartalov Andrijan, ${ }^{1}$ Petrovska Cvetkovska Dragana ${ }^{2}$

\footnotetext{
${ }^{1}$ University Clinic of Traumatology, Orthopedic Surgery, Anesthesiology, Intensive Care Unit and Emergency Center, ${ }^{2}$ University Clinic for Neurology, Faculty of Medicine, University "Ss. Cyril and Methodius" Skopje, Republic of Macedonia

Malnutricija je široki termin koji se koristi kada se
} \\ treba opisati svaki disbalans u ishrani. U 2009. bilo je po-
}


se malnutricija može pojaviti ili razviti su različiti. Kao posledica loše ishrane desi se gubitak na ćelijskom, fizičkom i fiziološkom nivou. Studije pokazuju da u hirurškoj praksi postoji malnutricija kod 50\% pacijenata i da postoji veza između neadekvatnog prehrambenog statusa i hirurškog rezultata. Malnutricija dovodi do produženog lečenja, povećanog nivoa morbiditeta i mortaliteta, povećanih bolničkih troškova itd. Ponekad malnutricija ostaje

\section{REFERENCES}

1. Naber TH, Schermer T, deBree A, et al. Prevalence of malnutrition in nonsurgical hospitalized patients and its association with disease complications. Am J Clin Nutr. 1997; 66(5): $1232-9$.

2. Holmes S. The effects of under nutrition in hospitalised patients. Nurs Stand. 2007; 22(12): 35-8.

3. Waitzberg DL, Ravacci GR, Raslan M. Hospital hyponutrition. Nutr Hosp. 2011; 26(2): 254-64.

4. STOP Disease-related Malnutrition: Prague Declaration June 2009 ENHA joins with the Czech Presidency of the EU Date: 22 June 2009.

5. Jensen GL. Inflammation as the key interface of the medical and nutrition universes: a provocative examination of the future of clinical nutrition and medicine. J Parenter Enteral Nutr. 2006; 30(5): 453-63.

6. Thorell A, Nygren J, Ljungqvist O. đnsulin resistance: a marker of surgical stress. Curr Opin Clin Nutr Metab Care. 1999; 2(1): 69-78.

7. Fearon KC, Ljungqvist $\mathrm{O}$, Von Meyenfeldt M, et al. Enhanced recovery after surgery: a consensus review of clinical care for patients undergoing colonic resection. Clin Nutr. 2005; 24(3): 466-77.

8. Strunin, L. How long should the patient fast before surgery? Time for new guidelines. Br J Anaesth.1993; 70(1): 1-3.

9. Green CR, Pandit SK, Schork MA. Preoperative fasting time: is the traditional policy changing? Results of a national survey. Anaesth Analg.1996; 83(1): 123-8.

10. Zelic M, Stimac D, Mendrila D, et al. Influence of preoperative oral feeding on stress response after resection for colon cancer. Hepatogastroenterology. 2012; 59(117): 1385-9.

11. El Nakeeb A, Fikry A, El Metwally T, et al. Early oral feeding in patients undergoing elective colonic anastomosis. Int J Surg. 2009; 7(3): 206-9.

12. Lewis SJ, Egger M, Sylvester PA, Thomas S. Early enteral feeding versus "nil by mouth" after gastrointestinal surgery: systematic review and meta-analysis of controlled trials. BMJ. 2001; 323(7316): 773-6.

13. Andersen HK, Lewis SJ, Thomas S. Early enteral nutrition within $24 \mathrm{~h}$ of colorectal surgery versus later commencement of feeding for postoperative complications. Cochrane Database Syst Rev. 2006; 4:CD004080.

14. Lewis SJ, Andersen HK, Thomas S. Early enteral nutrition within $24 \mathrm{~h}$ of intestinal surgery versus later commencement of feeding: a systematic review and meta-analysis. J Gastrointest Surg. 2009; 13(3): 569-75.

15. Drover JW, Cahill NE, Kutsogiannis J, et al. Nutrition therapy for the critically ill surgery patient: we need to do better! J Parenter Enteral Nutri. 2010; 34(6): 644-52. neprepoznata, što dovodi do njenog pogoršanja i nedovoljnog lečenja. Iz tog razloga cilj ovog rada je da elaborira patofiziološke mehanizme kod hirurškog pacijenata, procenu prehrambenog statusa, kao i enteralnu i parenteralnu ishranu u cilju utvrđivanja uslova i procedura koji utiču na izgled, prepoznavanje i tretman malnutricije.

Ključne reči: malnutricija, hirurški pacijent, enteralna ishrana, parenteralna ishrana.

16. Correia MI, Campos AC,ELAN Cooperative Study. Prevalence of hospital malnutrition in Latin America: the multicenter ELAN study. Nutrition. 2003; 19(10): 823-5.

17. Mueller C, Compher C, Ellen DM. A.S.P.E.N. clinical guidelines: nutrition screening, assessment and intervention in adults. J Parenter Enteral Nutri. 2011; 35(1): 16-24.

18. Blackburn GL, Bistrian BR, Maini BS, Schlamm HT, Smith MF. Nutritional and metabolic assessment of the hospitalized patient.J Parenter Enteral Nutr. 1977; 1(1): 11-21.

19. Dewys WD, Begg C, Lavin PT, et al. Prognostic effect of weight loss prior to chemotherapy in cancer patients. Eastern Cooperative Oncology Group. Am J Med. 1980; 69(4): 491-7.

20. Meguid MM, Debonis D, Meguid V, Hill LR, Terz JJ. Complications of abdominal operations for malignant disease. Am J Surg. 1988; 156(5): 341-5.

21. Meguid MM, Campos ACL, Meguid V, Debonis D, Terz JJ. IONIP, a criterion of surgical outcome and patient selection for perioperative nutritional support. Br J ClinPract Suppl. 1988; 63:8-14.

22. Klidjian AM, Foster KJ, Kammerling RM, Cooper A, Karran SJ. Relation of anthropometric and dynamometric variables to serious post-operative complications. Br Med J. 1980; 281(6245): 899-901.

23. Sungurtekin H, Sungurtekin U, Balci C, Zencir M, Erdem E. The influence of nutritional status on complications after major intraabdominal surgery.J Am CollNutr. 2004; 23(3): 227-32.

24. Detsky AS, Baker JP, O'Rourke K, et al. Predicting nutrition-associated complications for patients undergoing gastrointestinal surgery. J Parenter Enteral Nutr. 1987; 11(5): 440-6.

25. Gheorghe C, Pascu O, Iacob R, et al. Nutritional risk screening and prevalence of malnutrition on admission to gastroenterology departments: a multicentric study. Chirurgia (Bucur) 2013; 108(4): 535-41.

26. Rodriguez Bugueiro J, Lacquaniti N, Merkel MC, Villagra A. Active nutrition policy in the implementation of the hospital nutritional support; results of an observational study. Nutr Hosp. 2014; 30(2): 447-52.

27. Fuhrman MP, Charney P, Mueller CM. Hepatic proteins and nutrition assessment. J Am Diet Assoc. 2004; 104(8): 1258-64.

28. Jie B, Jiang ZM, Nolan MT, Zhu SN, Yu K, Kondrup J. Impact of preoperative nutritional support on clinical outcome in abdominal surgical patients at nutritional risk.Nutrition. 2012; 28(10): 1022-7.

29. Long CL, Schaffel N, Geiger JW, Schiller WR, Blakemore WS. Metabolic response to injury and illness: Estimation of energy and protein needs from indirect calorimetry and nitrogen balance. J Parent Enteral Nutr.1979; 3(6): 452-6. 
30. Doley J, Mallampalli A, Sandberg M. Nutrition management for the patient requiring prolonged mechanical ventilation. NutrClinPract. 2011; 26(3): 232-41.

31. Cerra FB, Benitez MR, Blackburn GL, et al. Applied nutrition in ICU patients: a consensus statement of the American College of Chest Physicians. Chest.1997; 111(3): 769-78.

32. MacDonald A, Hildebrandt L. Comparison of formulaic equations to determine energy expenditure in the critically ill patient. Nutrition. 2003; 19(3): 233-9.33. HarrisJA, BenedictFG. A biometric study of basal metabolism in man. Washington, DC: Carnegie Institute of Washington; 1919.

34. Krenitsky J. Adjusted body weight, pro: evidence to support the use of adjusted body weight in calculating calorie requirements. Nutr Clin Pract. 2005; 20(4): 468-73.

35. Haugen HA, Chan LN, Li F. Indirect calorimetry: a practical guide for clinicians. Nutr Clin Pract. 2007; 22(4): 377-88.

36. McClave SA, Lowen CC, Kleber MJ, McConnell W, Jung LY, Goldsmith Lj. Clinical use of the respiratory quotient obtained from indirect calorimetry. J Parenter Enteral Nutr. 2003; 27(1): 21-6.

37. Stapel SN, de Grooth HJ, Alimohamad H, et al. Ventilator derived carbon-dioxide production to assess energy expenditure in critically ill patients: proof of concept. Crit Care. 2015; 19:370. doi: 10.1186/s13054-015-1087-2.

38. WooleyJA, SaxHC. Indirect calorimetry: applications to practice. NutrClinPract. 2003; 18(5): 434-9.

39. Weimann A, Braga M, Harsanyi L, et al. ESPEN guidelines on enteral nutrition: surgery including organ transplantation. ClinNutr. 2006; 25(2): 224-44.

40. Sandstrom R, Drott C, Hyltander A,et al. The effect of postoperative intravenous feeding (TPN) on outcome following major surgery evaluated in a randomized study. Ann Surg. 1993; 217(2): 185-95.

41. Von Meyenfeldt MF, Meijerink WJ, Roufflart MM, Builmaassen MT, Soeters PB. Perioperative nutritional support: a randomized clinical trial. Clin Nutr. 1992; 11(4): 180-6.

42. Crowe PJ, Dennison A, Royle GT. The effect of pre-operative glucose loading on postoperative nitrogen metabolism. Br J Surg. 1984; 71(8): 635-7.

\section{Correspondence to / Autor za korespondenciju}

BiljanaAndonovska, MD

University Clinic for Anesthesiology and Intensive Care Faculty of Medicine, University "Ss. Cyril and Methodius"

Skopje, Republic of Macedonia

Tel: + 38970212880

E-mail: andonovska.biljana1@gmail.com
43. Druml W. Nutritional management of acute renal failure. Am J Kidney Dis. 2001; 37(Suppl.2): S89-94.

44. Machado De Sousa LR, Rodriques Ferreira SM, Madalozzo Schieferdecker ME. Physicochemical and nutricional characteristics of handmade enteral diets.Nutr Hosp. 2014; 29(3): 568-74.

45. Braga M, Gianotti L, Radaelli G, et al. Perioperative immunonutrition in patients undergoing cancer surgery: results of a randomized double-blind phase 3 trial. Arch Surg. 1999; 134(4): 428-33.

46. Senkal M, Mumme A, Eickhoff U, et al. Early postoperative enteral immunonutrition: clinical outcome and cost-comparison analysis in surgical patients. Crit Care Med. 1997; 25(9): 1489-96.

47. Braunschweig CL, Levy P, Sheean PM, Wang X. Enteral compared with parenteral nutrition: a meta-analysis. Am J ClinNutr. 2001; 74(4): 534-42.

48. Payne-James J., Grimble G., Silk D. Artificial Nutrition Support in Clinical Practice. Greenwich Medical Media Ltd, 2001.

49. Lowry SF. The route of feeding influences injury responses. J Trauma. 1990; 30(12 suppl): S10-5.

50. Lipman TO. Grains or veins: is enteral nutrition really better than parenteral nutrition? A look at the evidence. J Parenter Enteral Nutr. 1998; 22(3): 167-82.

51. Jie B, Jiang ZM, Nolan MT, et al. Impact of nutritional support on clinical outcome in patients at nutritional risk: a multicenter, prospective cohort study in Baltimore and Beijing teaching hospitals. Nutrition. 2010; 26(11-12): 1088-93.

52. Heidegger CP, Romand JA, Treggiari MM, Pichard C. Is it now time to promote mixed enteral and parenteral nutrition for the critically ill patients? Intensive Care Med. 2007; 33(6): 963-9.

53. Casaer MP, Mesotten D, Hermans G, et al. Early versus late parenteral nutrition in critically ill adults. $\mathrm{N}$ Engl $\mathrm{J}$ Med. 2011; 365(6): 506-17.

54. Hsu MH, Yu YE, Tsai YM, Lee HC, Huang YC, Hsu HS. Combined enteral feeding and total parenteral nutritional support improves outcome in surgical intensive care unit patients J Chin Med Assoc. 2012; 75(9): 459-63. 